\title{
Obesity and Cancer: Concepts and Challenges
}

\author{
Daniel F. Argol ${ }^{1,3}$ • Neil M. Iyengar ${ }^{1,2}$ • Clifford A. Hudis ${ }^{1,2}$
}

Received: 18 August 2015 / Accepted: 17 November 2015 /Published online: 23 November 2015

(C) Indian Association of Surgical Oncology 2015

\begin{abstract}
The rates of overweight and obesity are increasing worldwide in both developed and developing countries. Obesity is a major public health problem as it is associated with many diseases, including diabetes, hypertension, dyslipidemia, atherosclerosis, and some types of cancer. Breast cancer is a malignancy in which both the risk of development and the prognosis are negatively impacted by the obese state. The precise mechanisms pathophysiologically linking obesity and cancer are still under investigation. The biological basis for these associations includes both systemic and local tissue effects and white adipose tissue inflammation appears to be a critical component. A comprehensive understanding of the mechanisms linking obesity, inflammation and cancer may provide an opportunity for the development of strategies to attenuate the negative impact of obesity.
\end{abstract}

Keywords Obesity · Cancer · Breast cancer · Risk factors . Adipose tissue $\cdot$ Inflammation

\section{Introduction - Obesity as a Global Health Problem}

Overweight and obesity present a complex health problem that has been described as a global pandemic [1-3]. For adults, overweight and obesity categorizations are generally determined by using weight and height to calculate body mass

Daniel F. Argol

daniel.argolo@clion.com.br

1 Memorial Sloan Kettering Cancer Center, 300 East 66th Street -8 th floor, New York, NY 10065, USA

2 Weill Cornell Medical College, New York, NY, USA

3 CLION - CAM Group, Salvador, BA, Brazil index (BMI). The World Health Organization (WHO) categorizes overweight as a BMI between 25 and $29.9 \mathrm{~kg} / \mathrm{m}^{2}$ and obesity as a BMI $\geq 30 \mathrm{~kg} / \mathrm{m}^{2}$, however there is an active debate regarding the limitations of BMI to define obesity and overweight categories for various populations [4]. Regardless of the specific BMI cut-points used, in 2010 these elevated BMI categories were estimated to contribute to 3.4 million deaths worldwide and to account for $3.8 \%$ of global disabilityadjusted life-years lost [5]. Multiple studies have suggested growing rates of overweight and obesity around the world in recent decades [6-8]. In 2013, the number of overweight/ obese people in the world was estimated at 2.1 billion, representing almost one-third of the world's population [7]. Alarmingly, this trend toward increased overweight and obesity has been reported not only in adults, but also among children and adolescents [7].

The increase in overweight and obesity is seen in both developed and developing countries. In the United States (US), more than two-thirds of adults are considered to be overweight or obese and these rates continue to rise $[9,10]$. Estimates for the number of deaths attributable to obesity in the United States can be as high as 365,000 per year [11]. At least in the US, obesity and overweight have been described as important causes of possible declines in life expectancy later this century [12]. Medical costs related to obesity were estimated at \$147 billion in 2008 in the US [13], and these numbers could increase by $\$ 48$ to $\$ 66$ billion per year if the obesity rates continue to rise unchecked [14]. In 2006, the per capita medical costs for obese people were $\$ 1429(42 \%)$ higher than those of normal weight, across Medicare, Medicaid and private insurers [15].

Once considered a problem of developed countries, overweight and obesity are now increasing in developing countries, particularly in urban areas. In these countries, the rate of increase of childhood overweight and obesity has been more 
than $30 \%$ higher than in developed counterparts [16]. In addition, it was estimated that more than half of the world's obese people live in only ten countries (USA, China, India, Russia, Brazil, Mexico, Egypt, Germany, Pakistan, and Indonesia), and that two thirds of the obese are distributed among the developing nations [7].

As other developing countries, India is dichotomously affected with both overweight/obesity and underweight as major public health problems $[17,18]$. On one side of this spectrum, India has one of the highest numbers of undernourished children; on the other, diseases commonly related to overweight and obesity are also leading causes of disability and death [18]. The incidence of diabetes, hypertension and cardiovascular diseases associated with overweight and obesity are on the rise in India [19, 20], and it is estimated that the population affected by diabetes and hypertension will increase to more than 100 million and more than 214 million respectively by $2030[21,22]$. India probably contains the third largest number of obese citizens in the world in absolute numbers. Jointly with China, these two countries accounted for $15 \%$ of obese people worldwide in 2013 [7].

There are many diseases associated with obesity, including diabetes, hypertension, dyslipidemia, atherosclerosis, and cancer. In this article we focus on the relationships between obesity and malignances, specifically breast cancer. We review recent pathophysiologic insights, research findings and opportunities for intervention.

\section{Obesity and Malignances}

There are many sources of epidemiological data linking obesity to an increased risk of a range of solid tumors [23-25] and hematologic malignancies [25-27]. Obesity also increases risk for second primaries [28-30] and predicts worse prognosis in several types of cancer including those of the breast, esophagus, colon, prostate, kidney, ovary, uterus, liver, tongue, and others [31-34]. In 2007, it was estimated that about 80,000 new patients were diagnosed with obesityattributable cancers [35]. In addition, overweight and obesity were implicated in at least $15 \%$ of total cancer-specificmortality in a very large study conducted in the United States [31].

Obesity has been associated with higher breast cancer risk across observational studies, meta-analyses, and systematic reviews in different populations, especially for estrogen receptor positive breast cancer in postmenopausal women [25, 36-39]. Additional evidence suggests that obese women are also at increased risk for development of triple-negative breast cancer compared to the non-obese [40]. Furthermore, it has been demonstrated that obese and overweight patients with breast cancer have a worse prognosis disease regardless of tumor subtype [31].
The precise mechanisms that could explain the pathophysiology of the obesity-cancer link are still under investigation. Nonetheless, there are data supporting the importance of both systemic and local tissue effects. Some mechanisms have been proposed, including the role of circulating sex hormones, insulin-IGF signaling, circulating adipokines, and more recently, adipose progenitor cells and the microbiome, which are described below.

\section{Proposed and Possible Mechanisms}

\section{Sex Hormones}

High levels of estrogens can promote tumorigenic effects directly or indirectly via complex mechanisms including DNA damage, genetic instability, and stimulation of cellular proliferation, angiogenesis, and mutations [41-43]. Studies have reported a positive association between elevated circulating estrogen levels and the risk of postmenopausal breast cancer $[44,45]$. After menopause, the production of estrogens occurs primarily in the peripheral adipose tissues via conversion of androgen precursors by the cytochrome P450 dependent enzyme aromatase, which is encoded by the CYP19 gene [32]. Thus the greater risk of hormone receptor positive breast cancer in overweight/obese postmenopausal women has been attributed, in part, to increased estrogen production as a consequence of hyperadiposity [36]. However, despite this increased level of peripherally produced estrogen in overweight/obese patients, circulating estradiol levels are generally much lower in the postmenopausal versus premenopausal state. Nonetheless, the incidence of estrogen-driven breast cancers rises with age and is, therefore, more common in the postmenopausal subgroup despite the cessation of ovarian function [46]. Because pro-inflammatory mediators can activate CYP19, the gene encoding aromatase, it was proposed that this paradoxical increase in the incidence of hormone sensitive breast cancer after menopause may be plausibly explained by the recently described obesity-inflammationaromatase axis, which will be detailed later [47].

\section{Insulin and Insulin-Like Growth Factor (IGF)}

Diabetes and insulin resistance have been associated with increased incidence and worse prognosis for several types of cancer [48-51]. High levels of circulating insulin (reflecting insulin resistance) are associated with increased BMI and can contribute to cancer development directly (due to mitogenic effects) and indirectly (due to IGF signaling) [52, 53]. In addition, circulating total IGF-1 has also been positively associated with cancer risk, including breast malignances [54, 55]. The insulin-IGF signaling axis is a complex system and several mechanisms have been proposed to explain these 
associations. Studies have reported that both IGF and insulin interact with estrogen signaling pathways to promote the growth of hormone dependent breast cancers [56]. In obesity, it has been suggested that increased insulin levels stimulate lipolysis [57] and release high amounts of free-fatty acids into the circulation, leading to alterations related to the metabolic syndrome and worsening of hyperadiposity state [58]. Targeting IGF-1 receptor has not, however, yet been successful in breast cancer prevention or treatment suggesting even greater complexity in this pathway [59].

\section{Circulating Adipokines}

Adipokines are adipocyte-derived hormones that have regulatory effects on caloric intake and metabolism, as well as a role in angiogenesis and cell growth. Among their subtypes, leptin and adiponectin seem to have more important roles in the pathophysiology of cancer development and its progression [60-62].

Adiponectin, which is secreted only by mature adipocytes, is the most abundant adipokine and has anti-inflammatory activity [63]. Serum levels of adiponectin have an inverse correlation with BMI and epidemiologic and preclinical data suggest a protective effect for increased adiponectin levels on obesity-related cancer risk [64-67].

Leptin, which is increased in the obese state, is an important hormone for appetite regulation and energy balance with pro-inflammatory effects. Some studies suggest that high levels of leptin could be associated with increased risk of cancer; however, the data regarding this are conflicting [68, 69]. In this context, the leptin:adiponectin ratio seems to have a greater importance when compared to the isolated levels of these hormones when considering the cancer risk related to the metabolic health of the adipose tissues [70].

\section{White Adipose Tissue (WAT)-Derived Progenitor Cells}

In mice, studies have suggested that mesenchymal stromal cells (MSC) are commonly recruited to tumor sites by pathological signals including hypoxia and inflammation, thereby promoting angiogenesis and tumor progression. Evidence indicates that MSC may arise not only from bone marrow but also from white adipose tissue [71]. Therefore, in the context of obesity, a higher quantity of WAT-derived progenitor cells is expected and this could be another important link to be evaluated further.

\section{The Microbiome}

About 500-1000 different species coexist in the human intestine, totaling approximately 100 trillion organisms living in a symbiotic relationship with their individual hosts [72]. Variations on the composition of the intestinal microbiota are commonly related to diet, nutritional state and some health conditions, including obesity [73, 74]. Studies have found associations between the intestinal microbiome and some diseases [75], as an effect of their pathogenic activities and their metabolites. In addition, recent data suggest that the intestinal microbiome can also be involved in the pathogenesis of some non-intestinal diseases [75-79], including cancer (at least in mice) [80], probably due to the distribution of these microbial metabolites into the host circulation. The potential relationships between the microbiome and cancer are complex. It is speculated that these interactions can occur in different ways, including changes in the balance of host cell proliferation, immune system function, and also in the metabolism of host-produced factors, ingested foods and pharmaceuticals [81]. This is a novel and promising field and needs further investigation.

\section{Inflammation: The Emerging Link Between Obesity and Cancer}

The connections between inflammation and cancer have long been described. Earlier observations reported that many cancers occur at sites of chronic inflammation. Later epidemiologic data demonstrating that cancer rates are increased in patients with chronic inflammatory conditions led to the recognition of inflammation as an important contributor to neoplasm development [82]. Pathophysiologically, the tumor microenvironment has been classically described as a wound that will not heal and microscopically includes infiltration by immune cells, production of pro-inflammatory mediators, angiogenesis and tissue remodeling. This resource-rich environment may contribute to the development and promotion of malignant cells as well as enhanced tumor growth, invasion and distant metastasis [83].

Obesity is now a recognized etiology of chronic and subclinical inflammation [24, 84-86]. This low grade, smoldering inflammation has been associated with cancer development and promotion [87]. Several inflammatory biomarkers are commonly increased in obese individuals and data suggests a positive correlation between their levels in blood (TNF- $\alpha$; IL-6) [62] and urine ( $\mathrm{PGE}_{2}$ metabolites) [88] with development and/or progression of breast tumors. In the complex context of systemic inflammation, circulating chemokines are active not only in recruiting monocytes to adipose tissue, but also through the stimulation of macrophage proliferation in the fat pad [89] that contributes to a continuous positive feedback system for local WAT inflammation.

The complex interactions between adipocytes and immune cells in WAT have been the subject of many studies in recent years and the advances in understanding this area have generated new opportunities to explore cause and effect relationships between adipose inflammation and cancer. In mouse models of obesity and in obese humans, macrophages 
infiltrate visceral and subcutaneous adipose tissue and surround dead or dying adipocytes, forming characteristic crown-like structures (CLS) [84, 86, 90, 91]. WAT inflammation is defined by the presence of these inflammatory foci. These same structures also occur in the mammary glands of obese mice [47] and in the breast tissue of obese women, where they are termed CLS-B (for CLS of the breast) [92]. The presence of CLS-B (Fig. 1) is associated with activation of NF-KB, leading to increased production of TNF- $\alpha$, IL1 $\beta$ and COX-2 $[47,92]$. Importantly, these pro-inflammatory mediators are known inducers of CYP19 transcription, leading to increased aromatase expression and activity in the breast, as described earlier [93-99]. Collectively, these findings establish the potential role of adipose inflammation, which occurs most often in the context of obesity, in the promotion of local tissue-level estrogen signaling. This places local inflammation at the center of breast cancer pathogenesis for many women and partially addresses the longstanding clinical paradox of the increased incidence of hormone-sensitive breast cancer following the decline of ovarian function (and estrogen production) at menopause.

WAT inflammation has a positive association with BMI [100] and also is associated with alterations consistent with the metabolic syndrome [101]. In a prospective study conducted by our group, CLS-B was present in 43/48 (90\%) obese and 39/73 (53\%) overweight patients. In addition, the postmenopausal state was independently associated with the presence of CLS-B and also with more severe inflammation as evidenced by greater numbers of CLS-B $/ \mathrm{cm}^{2}$. Alarmingly, we also demonstrated that WAT inflammation is found in up to one third of normal weight women, who probably have the same detrimental biology as obese patients. These observations are possibly aligned with the phenotypic definition of metabolically healthy obesity (MHO) and metabolically unhealthy obesity (MUHO) previously reported in a nononcologic population [102].

Today the assessment of WAT inflammation requires a pathological evaluation of adipose tissue and this represents a major limitation in terms of broad application as a clinically useful tool. Therefore, several efforts have been made to develop a non-invasive method that can predict CLS-B and its consequences and we have ongoing studies addressing this possibility. It is also a limitation that most of the data regarding WAT inflammation and breast cancer was generated from a predominantly Caucasian population in the United States. Studies of CLS-B distribution in other populations are needed.

Studies evaluating strategies to reduce the breast cancer risk by targeting inflammation have been conducted in the past years and have conflicting results [103-105]. In these studies, patients were included irrespective of any inflammatory biomarker and this could be a plausible explanation for their mixed conclusions. We believe that a precise assessment of inflammation status represents an important step to develop a meaningful intervention aiming to reduce the cancer risk in the targeted population. Of particular interest in this scenario, interventions with non-steroidal anti-inflammatory drugs (NSAIDs), statins, omega-3 fatty acids, exercise programs and specific diets are to be tested prospectively in future studies.

\section{Conclusions and Perspectives}

Obesity is a growing and major public health problem around the world and has been considered by many as a pandemic in the new millennium. Many diseases have been consistently related to obesity, including malignances such as breast cancer. Therefore, we see at least four large challenges as important in this context (Fig. 2). They should be addressed simultaneously.

First, in alignment with the American Society of Clinical Oncology position statement on obesity and cancer [106], we need measures focused on both prevention and availability of adequate treatments for obesity reduction. This step contemplates educational measures (highlighting the importance of a balanced nutrition and exercises to maintain or achieve a
Fig. 1 CLS-B identified by Hematoxylin and eosin stain (a) and by anti-CD68 immunostain (b) Reprinted from Morris, P., et al.: Cancer Prev Res Vol. 4(7), 2011:1021-9

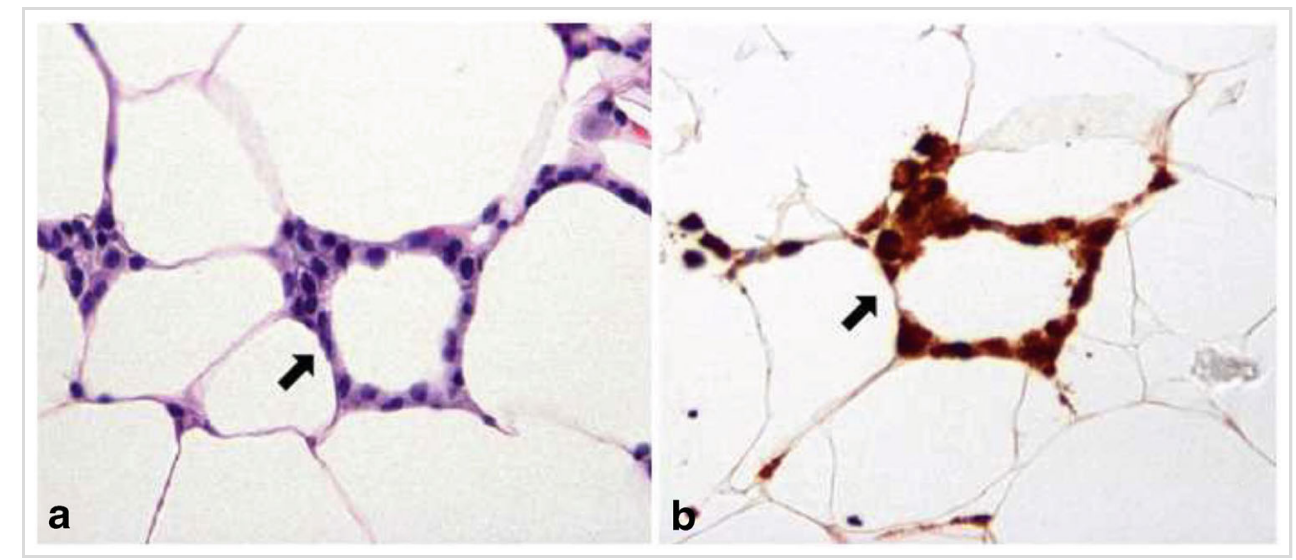


Fig. 2 Schema representing obesity current challenges

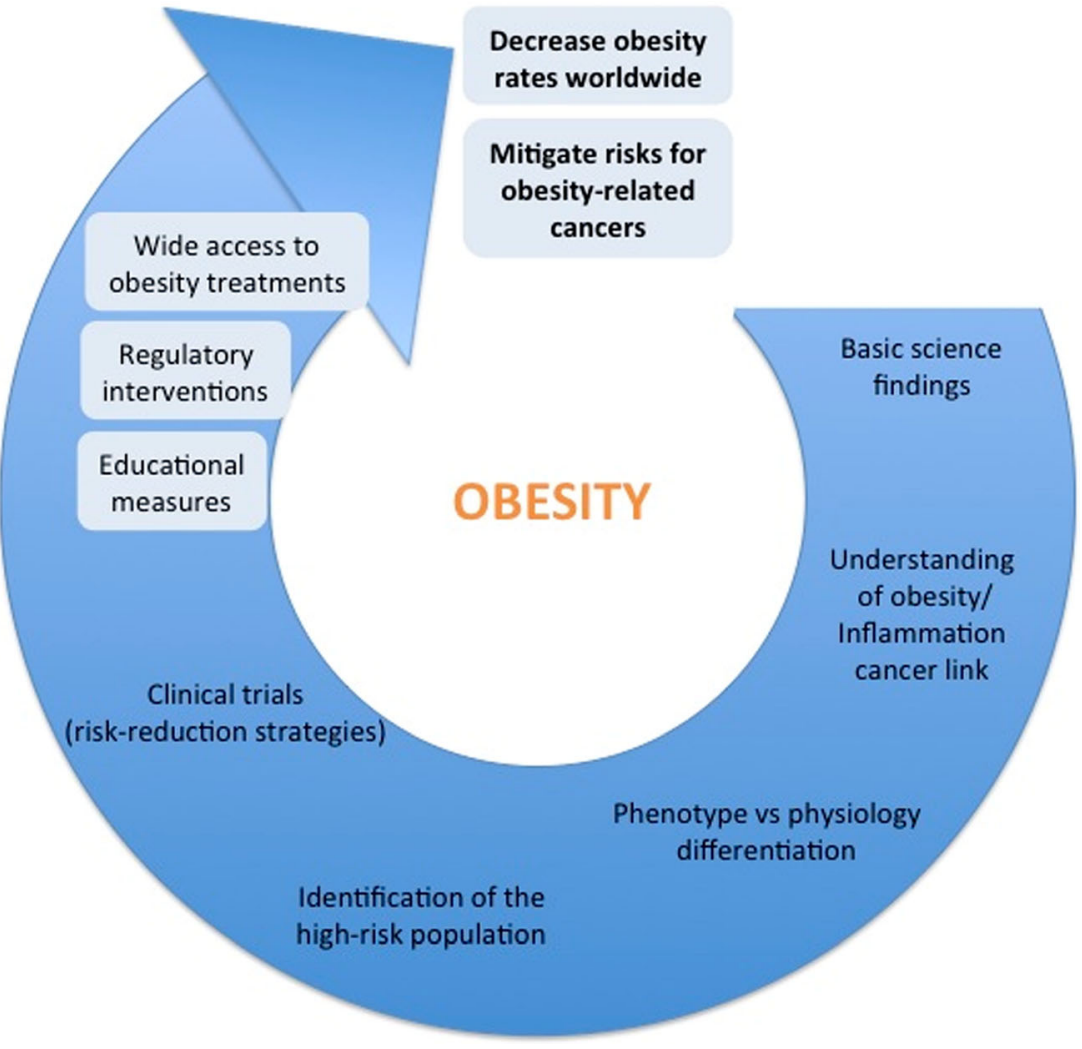

healthy lifestyle), wide access to multidisciplinary obesity treatment facilities and also possible regulatory interventions. Educational measures are important but have not been sufficient in the past as many other groups have been confronting this issue for decades. Using tobacco control as a model, some countries have attempted legislation aiming at the control of obesity. Although it is a controversial topic and open to many criticisms as it may interfere with perceived personal choices, this approach can be an important step to raise awareness and possibly reduce or limit the rising numbers of obese individuals worldwide. On the other hand, in the developing countries, this fight seems to be even more challenging, particularly because obesity coexists with the challenges of extreme poverty and malnutrition in many cases. In these countries, the implementation of public health programs to control both nutritional scenarios is critical.

A second but not less important challenge is related to our deepening understanding of the relationships between the hyperadiposity state and its associated health conditions, specifically some types of cancer. As described above, a comprehensive understanding of the obesity-cancer links may provide an enormous window of opportunity for the development of strategies to mitigate the obesity-related risks even if we cannot reverse or prevent obesity itself.

The third challenge is to separate phenotype from physiology. From the deeper pathophysiological insights we have gained, we and others have come to understand that the conventional BMI categorizations may be insufficient to identify metabolically unhealthy individuals who happen to have normal weights $[100,102]$. The point is illustrated by the observation that some people labeled as obese by existing BMI categories do not have any health conditions commonly related to obesity, including WAT inflammation, while on the other end of the spectrum there are those with normal BMIs who have pathological and clinical findings classically associated with obesity. We will need to better identify the truly "metabolically unhealthy obese" across all BMI categories if we wish to effectively intervene and improve population health. It is urgent to identify this population using noninvasive methods, probably through a more accurate body composition assessment, or a personal metabolic profile acquired from a blood-based signature or both.

Finally, as a fourth challenge, after identifying the high-risk population for either cancer development or poor prognosis, intervention strategies will need to be tested prospectively in randomized clinical trials. These can include assisted exercise training, specific nutritional programs, or pharmacological interventions, including but not limited to NSAIDs, metformin and statins as well as so-called nutraceuticals.

The identification of obesity as a global public health problem is clear. Next we need to implement policies informed by our improved understanding of its pathophysiology to attenuate the potentially catastrophic damage caused by this pandemic condition. 


\section{Compliance with Ethical Standards}

Conflict of Interest All authors declare that they have no conflict of interest.

Funding/Grant Support 2014 Conquer Cancer Foundation of ASCO LIFe Award (to Daniel F. Argolo).

Breast Cancer Research Foundation (to Clifford A. Hudis and Neil M. Iyengar).

\section{References}

1. Popkin BM, Adair LS, Ng SW (2012) Global nutrition transition and the pandemic of obesity in developing countries. Nutr Rev 70(1):3-21. doi:10.1111/j.1753-4887.2011.00456.x

2. Swinburn BA, Sacks G, Hall KD, McPherson K, Finegood DT, Moodie ML, Gortmaker SL (2011) The global obesity pandemic: shaped by global drivers and local environments. Lancet 378(9793):804-814. doi:10.1016/S0140-6736(11)60813-1

3. Roth J, Qiang X, Marban SL, Redelt H, Lowell BC (2004) The obesity pandemic: where have we been and where are we going? Obes Res 12(Suppl 2):88S-101S. doi:10.1038/oby.2004.273

4. Shah NR, Braverman ER (2012) Measuring adiposity in patients: the utility of body mass index (bmi), percent body fat, and leptin. PLoS One 7(4):e33308. doi:10.1371/journal.pone.0033308

5. Lim SS, Vos T, Flaxman AD, Danaei G, Shibuya K, Adair-Rohani $\mathrm{H}$, Memish ZA, et al. (2012) A comparative risk assessment of burden of disease and injury attributable to 67 risk factors and risk factor clusters in 21 regions, 1990-2010: A systematic analysis for the global burden of disease study 2010. Lancet 380(9859):2224 2260. doi:10.1016/S0140-6736(12)61766-8

6. Finucane MM, Stevens GA, Cowan MJ, Danaei G, Lin JK, Paciorek CJ, Global burden of metabolic risk factors of chronic diseases collaborating G, et al. (2011) national, regional, and global trends in body-mass index since 1980: systematic analysis of health examination surveys and epidemiological studies with 960 country-years and 9.1 million participants. Lancet 377(9765): 557-567. doi:10.1016/S0140-6736(10)62037-5

7. Ng M, Fleming T, Robinson M, Thomson B, Graetz N, Margono C, Gakidou E, et al. (2014) Global, regional, and national prevalence of overweight and obesity in children and adults during 1980-2013: A systematic analysis for the global burden of disease study 2013. Lancet 384(9945):766-781. doi:10.1016/S01406736(14)60460-8

8. Stevens GA, Singh GM, Lu Y, Danaei G, Lin JK, Finucane MM, Global Burden Of Metabolic Risk Factors Of Chronic Diseases Collaborating G, et al. (2012) National, regional, and global trends in adult overweight and obesity prevalences. Popul Health Metrics 10(1):22. doi:10.1186/1478-7954-10-22

9. Ogden CL, Carroll MD, Kit BK, Flegal KM (2014) Prevalence of childhood and adult obesity in the United States, 2011-2012. JAMA 311(8):806-814. doi:10.1001/jama.2014.732

10. National Institutes of Health (2012) Overweight and obesity statistics. http://win.niddk.nih.gov/publications/PDFs/stat904z.pdf. Accessed 19 March 2015

11. Flegal KM, Graubard BI, Williamson DF, Gail MH (2005) Excess deaths associated with underweight, overweight, and obesity. JAMA 293(15):1861-1867. doi:10.1001/jama.293.15.1861

12. Olshansky SJ, Passaro DJ, Hershow RC, Layden J, Carnes BA, Brody J, Ludwig DS, et al. (2005) A potential decline in life expectancy in the United States in the 21st century. N Engl J Med 352(11):1138-1145. doi:10.1056/NEJMsr043743

13. Finkelstein EA, Trogdon JG, Cohen JW, Dietz W (2009) Annual medical spending attributable to obesity: payer-and service-specific estimates. Health Aff 28(5):w822-w831. doi:10.1377/hlthaff. 28.5.w822

14. Wang YC, McPherson K, Marsh T, Gortmaker SL, Brown M (2011) Health and economic burden of the projected obesity trends in the USA and the UK. Lancet 378(9793):815-825. doi: 10.1016/S0140-6736(11)60814-3

15. Centers for Disease Control and Prevention (2015) Adult obesity facts. http://www.cdc.gov/obesity/data/adult.html. Accessed 24 July 2015

16. Word Health Oganization (2015) Obesity and overweight. http:// www.who.int/mediacentre/factsheets/fs $311 /$ en/. Accessed 23 July 2015

17. Wang Y, Chen HJ, Shaikh S, Mathur P (2009) Is obesity becoming a public health problem in India? Examine the shift from under- to overnutrition problems over time. Obesity Reviews : an Official Journal of the International Association for the Study of Obesity 10(4):456-474. doi:10.1111/j.1467-789X.2009.00568.x

18. Khandelwal S, Reddy KS (2013) Eliciting a policy response for the rising epidemic of overweight-obesity in India. Obesity Reviews : An Official Journal of the International Association for the Study of Obesity 14(Suppl 2):114-125. doi:10.1111/obr. 12097

19. Jayawardena R, Ranasinghe P, Byrne NM, Soares MJ, Katulanda P, Hills AP (2012) Prevalence and trends of the diabetes epidemic in South Asia: a systematic review and meta-analysis. BMC Public Health 12:380. doi:10.1186/1471-2458-12-380

20. Siddiqui ST, Kandala NB, Stranges S (2015) Urbanisation and geographic variation of overweight and obesity in India: A cross-sectional analysis of the Indian demographic health survey 2005-2006. International Journal of Public Health. doi:10.1007/ s00038-015-0720-9

21. Gupta R, Guptha S, Sharma KK, Gupta A, Deedwania P (2012) Regional variations in cardiovascular risk factors in India: India heart watch. World J Cardiol 4(4):112-120. doi:10.4330/wjc.v4. i4.112

22. Devi P, Rao M, Sigamani A, Faruqui A, Jose M, Gupta R, Xavier D, et al. (2013) Prevalence, risk factors and awareness of hypertension in India: A systematic review. J Hum Hypertens 27(5): 281-287. doi:10.1038/jhh.2012.33

23. Calle EE, Kaaks R (2004) Overweight, obesity and cancer: epidemiological evidence and proposed mechanisms. Nat Rev Cancer 4(8):579-591. doi:10.1038/nrc1408

24. van Kruijsdijk RC, van der Wall E, Visseren FL (2009) Obesity and cancer: The role of dysfunctional adipose tissue. Cancer epidemiology, biomarkers \& prevention : A publication of the American association for cancer research, cosponsored by the American society of preventive oncology 18 (10):2569-2578. doi:10.1158/1055-9965.EPI-09-0372

25. Renehan AG, Tyson M, Egger M, Heller RF, Zwahlen M (2008) Body-mass index and incidence of cancer: A systematic review and meta-analysis of prospective observational studies. Lancet 371(9612):569-578. doi:10.1016/S0140-6736(08)60269-X

26. Beason T, Colditz G (2012) Obesity and multiple myeloma. In: Mittelman SD, Berger NA (eds) Energy balance and hematologic malignancies. Energy balance and cancer, vol 5, 1st edn. Springer US, pp 71-95. doi:10.1007/978-1-4614-2403-1

27. Terras LR, Patel AV (2012) The epidemiology of obesity and hematologic malignancies. In: Mittelman SD, Berger NA (eds) Energy balance and hematologic malignancies. Energy balance and cancer, vol 5, 1st edn. Springer US, pp 1-30. doi:10.1007/ 978-1-4614-2403-1 
28. Li CI, Daling JR, Porter PL, Tang MT, Malone KE (2009) Relationship between potentially modifiable lifestyle factors and risk of second primary contralateral breast cancer among women diagnosed with estrogen receptor-positive invasive breast cancer. J Clin Oncol Off J Am Soc Clin Oncol 27(32):5312-5318. doi:10. 1200/JCO.2009.23.1597

29. Li D, Morris JS, Liu J, Hassan MM, Day RS, Bondy ML, Abbruzzese JL (2009) Body mass index and risk, age of onset, and survival in patients with pancreatic cancer. JAMA 301(24): 2553-2562. doi:10.1001/jama.2009.886

30. Park JS, Choi GS, Jang YS, Jun SH, Kang H (2010) Influence of obesity on the serum carcinoembryonic antigen value in patients with colorectal cancer. Cancer Epidemiology, Biomarkers \& Prevention : A Publication of the American Association for Cancer Research, Cosponsored by the American Society of Preventive Oncology 19(10):2461-2468. doi:10.1158/10559965.EPI-10-0569

31. Calle EE, Rodriguez C, Walker-Thurmond K, Thun MJ (2003) Overweight, obesity, and mortality from cancer in a prospectively studied cohort of U.S. adults. N Engl J Med 348(17):1625-1638. doi:10.1056/NEJMoa021423

32. Iyengar NM, Hudis CA, Dannenberg AJ (2013) Obesity and inflammation: new insights into breast cancer development and progression. American Society of Clinical Oncology educational book/ASCO American Society of Clinical Oncology Meeting: 46-51. doi:10.1200/EdBook_AM.2013.33.46

33. Iyengar NM, Morris PG, Hudis CA, Dannenberg AJ (2013) Obesity, inflammation, and breast cancer. In: Dannenberg AJ, Berger NA (eds) Obesity, Inflammation and cancer. Energy balance and cancer, vol 7, 1st edn. Springer-Verlag New York, pp 181-217. doi:10.1007/978-1-4614-6819-6

34. Yoon HH, Lewis MA, Shi Q, Khan M, Cassivi SD, Diasio RB, Sinicrope FA (2011) Prognostic impact of body mass index stratified by smoking status in patients with esophageal adenocarcinoma. J Clin Oncol Off J Am Soc Clin Oncol 29(34):4561-4567. doi:10.1200/JCO.2011.37.1260

35. National Cancer Institute (2012) Obesity and Cancer risk. http:// www.cancer.gov/cancertopics/causes-prevention/risk/weightactivity/obesity-fact-sheet. Accessed 19 March 2015

36. Cleary MP, Grossmann ME (2009) Minireview: Obesity and breast cancer: The estrogen connection. Endocrinology 150(6): 2537-2542. doi:10.1210/en.2009-0070

37. World Cancer Research Fund / American Institute for Cancer Research (2007) Food, nutrition, physical activity, and the prevention of cancer: a global perspective. AICR, Washington DC

38. Suzuki R, Orsini N, Saji S, Key TJ, Wolk A (2009) Body weight and incidence of breast cancer defined by estrogen and progesterone receptor status-a meta-analysis. International Journal of Cancer Journal International du Cancer 124(3):698-712. doi:10. 1002/ijc. 23943

39. Singh P, Kapil U, Shukla N, Deo S, Dwivedi S (2011) Association of overweight and obesity with breast cancer in India. Indian Journal of Community Medicine : Official Publication of Indian Association of Preventive \& Social Medicine 36(4):259-262. doi: 10.4103/0970-0218.91326

40. Pierobon M, Frankenfeld CL (2013) Obesity as a risk factor for triple-negative breast cancers: a systematic review and meta-analysis. Breast Cancer Res Treat 137(1):307-314. doi:10.1007/ s10549-012-2339-3

41. Travis RC, Key TJ (2003) Oestrogen exposure and breast cancer risk. Breast Cancer research : BCR 5(5):239-247. doi:10.1186/ bcr628

42. Yager JD, Davidson NE (2006) Estrogen carcinogenesis in breast cancer. N Engl J Med 354(3):270-282. doi:10.1056/ NEJMra050776
43. Pequeux C, Raymond-Letron I, Blacher S, Boudou F, Adlanmerini M, Fouque MJ, Lenfant F, et al. (2012) Stromal estrogen receptor-alpha promotes tumor growth by normalizing an increased angiogenesis. Cancer Res 72(12):3010-3019. doi: 10.1158/0008-5472.CAN-11-3768

44. Key TJ, Appleby PN, Reeves GK, Roddam A, Dorgan JF, Longcope C, Endogenous Hormones Breast Cancer Collaborative G, et al. (2003) Body mass index, serum sex hormones, and breast cancer risk in postmenopausal women. J Natl Cancer Inst 95(16): 1218-1226

45. Kaaks R, Rinaldi S, Key TJ, Berrino F, Peeters PH, Biessy C, Riboli E, et al. (2005) Postmenopausal serum androgens, oestrogens and breast cancer risk: the European prospective investigation into cancer and nutrition. Endocr Relat Cancer 12(4): 1071-1082. doi:10.1677/erc. 1.01038

46. Li CI, Daling JR, Malone KE (2003) Incidence of Invasive breast cancer by hormone receptor status from 1992 to 1998. J Clin Oncol Off J Am Soc Clin Oncol 21(1):28-34

47. Subbaramaiah K, Howe LR, Bhardwaj P, Du B, Gravaghi C, Yantiss RK, Dannenberg AJ, et al. (2011) Obesity is associated with inflammation and elevated aromatase expression in the mouse mammary gland. Cancer Prevention Research 4(3):329 346. doi:10.1158/1940-6207.CAPR-10-0381

48. Khandekar MJ, Cohen P, Spiegelman BM (2011) Molecular mechanisms of cancer development in obesity. Nat Rev Cancer 11(12):886-895. doi:10.1038/nrc3174

49. Pollak MN, Schernhammer ES, Hankinson SE (2004) Insulin-like growth factors and neoplasia. Nat Rev Cancer 4(7):505-518. doi: 10.1038/nrc1387

50. Goodwin PJ, Ennis M, Pritchard KI, Trudeau ME, Koo J, Madarnas Y, Hood N, et al. (2002) Fasting insulin and outcome in early-stage breast cancer: results of a prospective cohort study. J Clin Oncol Off J Am Soc Clin Oncol 20(1):42-51

51. Barone BB, Yeh HC, Snyder CF, Peairs KS, Stein KB, Derr RL, Brancati FL, et al. (2008) Long-term all-cause mortality in cancer patients with preexisting diabetes mellitus: a systematic review and meta-analysis. JAMA 300(23):2754-2764. doi:10.1001/ jama.2008.824

52. Giovannucci E (1995) Insulin and colon cancer. Cancer Causes Control 6(2):164-179

53. McKeown-Eyssen G (1994) Epidemiology of colorectal cancer revisited: are serum triglycerides and/or plasma glucose associated with risk? Cancer Epidemiology, Biomarkers \& Prevention : A Publication of the American Association for Cancer Research, Cosponsored by the American Society of Preventive Oncology 3(8):687-695

54. Clayton PE, Banerjee I, Murray PG, Renehan AG (2011) Growth hormone, the insulin-like growth factor axis, insulin and cancer risk. Nat Rev Endocrinol 7(1):11-24. doi:10.1038/nrendo.2010.171

55. Renehan AG, Zwahlen M, Minder C, O'Dwyer ST, Shalet SM, Egger M (2004) Insulin-like growth factor (IGF)-I, IGF binding protein-3, and cancer risk: systematic review and meta-regression analysis. Lancet 363(9418):1346-1353. doi:10.1016/S01406736(04)16044-3

56. Lueprasitsakul P, Latour D, Longcope C (1990) Aromatase activity in human adipose tissue stromal cells: effect of growth factors. Steroids 55(12):540-544

57. Rosen ED, Spiegelman BM (2014) What we talk about when we talk about fat. Cell 156(1-2):20-44. doi:10.1016/j.cell.2013.12. 012

58. Hofbauer KG (2002) Molecular pathways to obesity. Int J Obes Relat Metab Disord 26(Suppl 2):S18-S27. doi:10.1038/sj.ijo. 0802124

59. Robertson JF, Ferrero JM, Bourgeois H, Kennecke H, de Boer RH, Jacot W, Kaufman PA, et al. (2013) Ganitumab with either exemestane or fulvestrant for postmenopausal women with 
advanced, hormone-receptor-positive breast cancer: a randomised, controlled, double-blind, phase 2 trial. The Lancet Oncology 14(3):228-235. doi:10.1016/S1470-2045(13)70026-3

60. Fischer-Posovszky P, Wabitsch M, Hochberg Z (2007) endocrinology of adipose tissue - an update. Horm Metab Res 39(5):314 321. doi:10.1055/s-2007-976539

61. Tilg H, Moschen AR (2006) Adipocytokines: mediators linking adipose tissue, inflammation and immunity. Nat Rev Immunol 6(10):772-783. doi:10.1038/nri1937

62. Hursting SD, Digiovanni J, Dannenberg AJ, Azrad M, Leroith D, Demark-Wahnefried W, Berger NA, et al. (2012) Obesity, energy balance, and cancer: new opportunities for prevention. Cancer Prevention Research 5(11):1260-1272. doi:10.1158/1940-6207. CAPR-12-0140

63. Renehan AG, Zwahlen M, Egger M (2015) Adiposity and cancer risk: new mechanistic insights from epidemiology. Nat Rev Cancer 15(8):484 498. doi:10.1038/nrc3967

64. Grossmann ME, Nkhata KJ, Mizuno NK, Ray A, Cleary MP (2008) Effects of adiponectin on breast cancer cell growth and signaling. Br J Cancer 98(2):370-379. doi:10.1038/sj.bjc. 6604166

65. Cong L, Gasser J, Zhao J, Yang B, Li F, Zhao AZ (2007) Human adiponectin inhibits cell growth and induces apoptosis in human endometrial carcinoma cells, HEC-1-A and RL95 2. Endocr Relat Cancer 14(3):713-720. doi:10.1677/ERC-07-0065

66. Kim AY, Lee YS, Kim KH, Lee JH, Lee HK, Jang SH, Kim JB, et al. (2010) Adiponectin represses colon cancer cell proliferation via AdipoR1- and -R2-mediated AMPK activation. Mol Endocrinol 24(7):1441-1452. doi:10.1210/me.2009-0498

67. Bub JD, Miyazaki T, Iwamoto Y (2006) Adiponectin as a growth inhibitor in prostate cancer cells. Biochem Biophys Res Commun 340(4):1158-1166. doi:10.1016/j.bbrc.2005.12.103

68. Gialamas SP, Sergentanis TN, Antonopoulos CN, Dessypris N, Chrousos GP, Petridou ET (2013) Circulating leptin levels and risk of colorectal cancer and adenoma: a case-control study and meta-analysis. Cancer Causes Control 24(12):2129-2141. doi:10. 1007/s10552-013-0290-1

69. Renehan AG, Roberts DL, Dive C (2008) Obesity and cancer: pathophysiological and biological mechanisms. Arch Physiol Biochem 114(1):71-83. doi:10.1080/13813450801954303

70. Iyengar NM, Hudis CA, Dannenberg AJ (2015) Obesity and cancer: local and systemic mechanisms. Annu Rev Med 66:297-309. doi:10.1146/annurev-med-050913-022228

71. Bertolini F, Petit JY, Kolonin MG (2015) Stem cells from adipose tissue and breast cancer: hype, risks and hope. Br J Cancer 112(3): 419-423. doi:10.1038/bjc.2014.657

72. Kamada N, Seo SU, Chen GY, Nunez G (2013) Role of the gut microbiota in immunity and inflammatory disease. Nat Rev Immunol 13(5):321-335. doi:10.1038/nri3430

73. Ley RE, Turnbaugh PJ, Klein S, Gordon JI (2006) Microbial ecology: human gut microbes associated with obesity. Nature 444(7122):1022-1023. doi:10.1038/4441022a

74. Ley RE, Backhed F, Turnbaugh P, Lozupone CA, Knight RD, Gordon JI (2005) Obesity alters gut microbial ecology. Proc Natl Acad Sci U S A 102(31):11070-11075. doi:10.1073/pnas. 0504978102

75. Holmes E, Li JV, Marchesi JR, Nicholson JK (2012) Gut microbiota composition and activity in relation to host metabolic phenotype and disease risk. Cell Metab 16(5):559-564. doi:10.1016/j. cmet.2012.10.007

76. Henao-Mejia J, Elinav E, Jin C, Hao L, Mehal WZ, Strowig T, Flavell RA, et al. (2012) Inflammasome-mediated dysbiosis regulates progression of nafld and obesity. Nature 482(7384):179185. doi:10.1038/nature10809

77. Koeth RA, Wang Z, Levison BS, Buffa JA, Org E, Sheehy BT, Hazen SL, et al. (2013) Intestinal microbiota metabolism of 1- carnitine, a nutrient in red meat, promotes atherosclerosis. Nat Med 19(5):576-585. doi:10.1038/nm.3145

78. Yokote H, Miyake S, Croxford JL, Oki S, Mizusawa H, Yamamura T (2008) NKT cell-dependent amelioration of a mouse model of multiple sclerosis by altering gut flora. Am J Pathol 173(6):1714-1723. doi:10.2353/ajpath.2008.080622

79. Collins SM, Surette M, Bercik P (2012) The interplay between the intestinal microbiota and the brain. Nat Rev Microbiol 10(11): 735-742. doi:10.1038/nrmicro2876

80. Yoshimoto S, Loo TM, Atarashi K, Kanda H, Sato S, Oyadomari $\mathrm{S}$, Ohtani N, et al. (2013) Obesity-induced gut microbial metabolite promotes liver cancer through senescence secretome. Nature 499(7456):97-101. doi:10.1038/nature12347

81. Garrett WS (2015) Cancer and the microbiota. Science 348(6230): 80-86. doi:10.1126/science.aaa4972

82. Balkwill F, Mantovani A (2001) Inflammation and cancer: back to Virchow? Lancet 357(9255):539-545. doi:10.1016/S01406736(00)04046-0

83. Coussens LM, Werb Z (2002) Inflammation and cancer. Nature 420(6917):860-867. doi:10.1038/nature01322

84. Cancello R, Henegar C, Viguerie N, Taleb S, Poitou C, Rouault C, Clement K, et al. (2005) Reduction of macrophage infiltration and chemoattractant gene expression changes in white adipose tissue of morbidly obese subjects after surgery-induced weight loss. Diabetes 54(8):2277-2286

85. Cinti S, Mitchell G, Barbatelli G, Murano I, Ceresi E, Faloia E, Obin MS, et al. (2005) Adipocyte death defines macrophage localization and function in adipose tissue of obese mice and humans. J Lipid Res 46(11):2347-2355. doi:10.1194/j1r. M500294-JLR200

86. Olefsky JM, Glass CK (2010) Macrophages, inflammation, and insulin resistance. Annu Rev Physiol 72:219-246. doi:10.1146/ annurev-physiol-021909-135846

87. Balkwill F, Charles KA, Mantovani A (2005) Smoldering and polarized inflammation in the initiation and promotion of malignant disease. Cancer Cell 7(3):211-217. doi:10.1016/j.ccr.2005. 02.013

88. Morris PG, Zhou XK, Milne GL, Goldstein D, Hawks LC, Dang CT, Dannenberg AJ, et al. (2013) Increased levels of urinary pge$\mathrm{m}$, a biomarker of inflammation, occur in association with obesity, aging, and lung metastases in patients with breast cancer. Cancer Prevention Research 6(5):428-436. doi:10.1158/1940-6207. CAPR-12-0431

89. Amano SU, Cohen JL, Vangala P, Tencerova M, Nicoloro SM, Yawe JC, Aouadi M, et al. (2014) Local proliferation of macrophages contributes to obesity-associated adipose tissue inflammation. Cell Metab 19(1):162-171. doi:10.1016/j.cmet.2013.11.017

90. Murano I, Barbatelli G, Parisani V, Latini C, Muzzonigro G, Castellucci M, Cinti S (2008) Dead adipocytes, detected as crown-like structures, are prevalent in visceral fat depots of genetically obese mice. J Lipid Res 49(7):1562-1568. doi:10.1194/jlr. M800019-JLR200

91. Weisberg SP, McCann D, Desai M, Rosenbaum M, Leibel RL, Ferrante AW, Jr. (2003) Obesity is associated with macrophage accumulation in adipose tissue. J Clin Invest 112 (12):17961808. doi:10.1172/JCI19246

92. Morris PG, Hudis CA, Giri D, Morrow M, Falcone DJ, Zhou XK, Dannenberg AJ, et al. (2011) Inflammation and increased aromatase expression occur in the breast tissue of obese women with breast cancer. Cancer Prevention Research 4(7):1021-1029. doi: 10.1158/1940-6207.CAPR-11-0110

93. Hardy DB, Janowski BA, Chen CC, Mendelson CR (2008) Progesterone receptor inhibits aromatase and inflammatory response pathways in breast cancer cells via ligand-dependent and ligand-independent mechanisms. Mol Endocrinol 22(8):18121824. doi:10.1210/me.2007-0443 
94. Irahara N, Miyoshi Y, Taguchi T, Tamaki Y, Noguchi S (2006) Quantitative analysis of aromatase mRNA expression derived from various promoters (I.4, I.3, PII and I.7) and its association with expression of TNF-alpha, IL-6 and COX-2 mRNAs in human breast cancer. International Journal of Cancer Journal International du Cancer 118(8):1915-1921. doi:10.1002/ijc.21562

95. Salama SA, Kamel MW, Diaz-Arrastia CR, Xu X, Veenstra TD, Salih S, Kumar R, et al. (2009) Effect of tumor necrosis factoralpha on estrogen metabolism and endometrial cells: potential physiological and pathological relevance. The Journal of Clinical endocrinology and Metabolism 94(1):285-293. doi:10.1210/jc. 2008-1389

96. Subbaramaiah K, Hudis C, Chang SH, Hla T, Dannenberg AJ (2008) EP2 and EP4 receptors regulate aromatase expression in human adipocytes and breast cancer cells. Evidence of a BRCA1 and p300 exchange. The Journal of Biological Chemistry 283(6): 3433-3444. doi:10.1074/jbc.M705409200

97. Zhao Y, Agarwal VR, Mendelson CR, Simpson ER (1996) Estrogen biosynthesis proximal to a breast tumor is stimulated by PGE2 via cyclic AMP, leading to activation of promoter II of the CYP19 (Aromatase) gene. Endocrinology 137(12):57395742. doi:10.1210/endo.137.12.8940410

98. Zhao Y, Agarwal VR, Mendelson CR, Simpson ER (1997) Transcriptional regulation of CYP19 gene (Aromatase) expression in adipose stromal cells in primary culture. The Journal of Steroid biochemistry and Molecular Biology 61(3-6):203-210

99. Zhao Y, Nichols JE, Valdez R, Mendelson CR, Simpson ER (1996) Tumor necrosis factor-alpha stimulates aromatase gene expression in human adipose stromal cells through use of an activating protein-1 binding site upstream of promoter 1.4. Mol Endocrinol 10(11):1350-1357. doi:10.1210/mend.10.11.8923461
100. Iyengar NM, Morris PG, Zhou XK, Gucalp A, Giri D, Harbus MD, Dannenberg AJ, et al. (2015) Menopause is a determinant of breast adipose inflammation. Cancer Prevention research. doi: 10.1158/1940-6207.CAPR-14-0243

101. Iyengar NM, Gucalp A, Zhou XK, Howe LR, Morris PG, Giri D, et al. Dannenberg AJ (2015) Abstract P4-04-12: Both metabolic syndrome and statin use are more common in women with breast inflammation. Cancer research 75 (9 Supplement):P4-04-12. doi: 10.1158/1538-7445.sabcs14-p4-04-12

102. Seo MH, Rhee EJ (2014) Metabolic and cardiovascular implications of a metabolically healthy obesity phenotype. Endocrinol Metab (Seoul) 29(4):427-434. doi:10.3803/EnM.2014.29.4.427

103. Cook NR, Lee IM, Gaziano JM, Gordon D, Ridker PM, Manson JE, Buring JE, et al. (2005) Low-dose aspirin in the primary prevention of cancer: The women's health study: A randomized controlled trial. JAMA 294(1):47-55. doi:10.1001/jama.294.1.47

104. Takkouche B, Regueira-Mendez C, Etminan M (2008) Breast cancer and use of nonsteroidal anti-inflammatory drugs: A metaanalysis. J Natl Cancer Inst 100(20):1439-1447. doi:10.1093/jnci/ $\operatorname{djn} 324$

105. Zhang X, Smith-Warner SA, Collins LC, Rosner B, Willett WC, Hankinson SE (2012) Use of aspirin, other nonsteroidal antiinflammatory drugs, and acetaminophen and postmenopausal breast cancer incidence. J Clin Oncol Off J Am Soc Clin Oncol 30(28):3468-3477. doi:10.1200/JCO.2012.42.2006

106. Ligibel JA, Alfano CM, Courneya KS, Demark-Wahnefried W, Burger RA, Chlebowski RT, Hudis CA, et al. (2014) American Society of clinical oncology position statement on obesity and cancer. J Clin Oncol Off J Am Soc Clin Oncol 32(31):35683574. doi: $10.1200 / \mathrm{JCO} .2014 .58 .4680$ 